\title{
Technical efficacy and practicability of mass trapping for insect control in Bangladesh
}

\author{
Naznin Nahar ${ }^{1,2}$ (1) $\cdot$ Mohammad Mahir Uddin ${ }^{1} \cdot$ Peter de Jong ${ }^{2} \cdot$ Paul C. Struik $^{2} \cdot$ Tjeerd Jan Stomph $^{2}$
}

Accepted: 4 May 2020 / Published online: 9 June 2020

(C) The Author(s) 2020

\begin{abstract}
Eggplant shoot and fruit borer, Leucinodes orbonalis, is a major pest in eggplant production in South and South-East Asia. Farmers frequently spray insecticides to control it. Integrated pest management (IPM) based on mass trapping or pheromone trapping and sanitation (removal of infested shoots and fruits) has been suggested but poorly adopted. This study tested, together with farmers, combinations of IPM components that fit their farming practices, increase income, and preserve natural enemy populations. A 2-year participatory study was negotiated with these farmers, comparing (i) an untreated control, (ii) farmers' conventional weekly spraying, with pheromone trapping either (iii) alone, or combined with (iv) trap-based biorational spraying, or (v) bi-weekly conventional insecticide spraying. Farmers rejected testing sanitation as too labor-intensive. In both years, pheromone trapping alone or combined with biorational spraying reduced fruit infestation, increased yield and income, and preserved natural enemies, showing technical efficacy at costs comparable with farmers' practice. Replacing biorational spraying by conventional insecticides did not provide any control beyond pheromone trapping alone but reduced natural enemies. In contrast, farmers' practice neither reduced infestation nor increased yield but reduced populations of natural enemies. Aphid and jassid populations were reduced only by biorational and conventional spraying. As farmers were reluctant to use only pheromone trapping, the addition of biorational spraying might be suitable. Discussion with farmers allowed us to understand how practical applicability of the tested IPM depends on farmers' knowledge levels on insect biology, farmers' desire to still use some spraying, and labor constraints to sanitation. Although technically and economically viable, the tested IPM may prove difficult to scale out, as farmers had difficulty understanding the lifecycle of Leucinodes orbonalis and the pheromone trapping mechanisms. This study is the first to disentangle the technical efficacy of pheromone-trapping-based IPM from its practical applicability for the targeted smallholder eggplant growers.
\end{abstract}

Keywords Eggplant shoot and fruit borer $\cdot$ Integrated pest management $\cdot$ Pheromone trap $\cdot$ Biorational $\cdot$ Participatory study

\section{Introduction}

Eggplant (Solanum melongena L.) is economically one of the most important vegetable crops in many Asian countries, including Bangladesh. Farmers, especially small landholders, cultivate eggplant because of its prolonged fruiting period, generating cash income at least once per week for 4-6 months. However, income and production of this vegetable are

Naznin Nahar

naznin.nahar@wur.nl; naznin.nahar@bau.edu.bd

1 Faculty of Agriculture, Bangladesh Agricultural University, Mymensingh 2202, Bangladesh

2 Department of Plant Sciences, Wageningen University \& Research, 6708, PB Wageningen, The Netherlands severely constrained by the caterpillars of a moth, the eggplant shoot and fruit borer (ESFB), Leucinodes orbonalis Guenée (Lepidoptera: Pyralidae) (Alam et al. 2006; Srinivasan 2008). Yield losses of 30 to $90 \%$ have been reported (Srinivasan 2008). During the early vegetative stage, caterpillars penetrate shoot apices, causing these to drop off, thus impeding plant growth. During the fruiting stage, caterpillars mostly infest fruits. Caterpillars tunnel inside the fruit and fill it with excreta, the latter enhancing secondary infection, making the fruit usually unfit for sale and consumption (Srinivasan 2008).

The vast majority of farmers in Bangladesh rely exclusively on chemical insecticides to combat ESFB (Fig. 1a). Farmers spray a variety of broad-spectrum insecticides once per week to daily in the 6-month growing season (Mohiuddin et al. 2009) investing 30-50\% of input costs in insect control (Alam et al. 2006). Frequent use of insecticides threatens 
Fig. 1 a Farmers usually spray insecticides to control the caterpillars of a moth infesting eggplant shoots and fruits. b An alternative practice of mass trapping with pheromone lures is available, in our experiments traps of several adjacent fields formed a network. c Field discussions with farmers revealed that they have a poor knowledge of the moth's lifecycle. This restrains their acceptance to limit pest control to traps only, and explains why they are asking also for some spraying

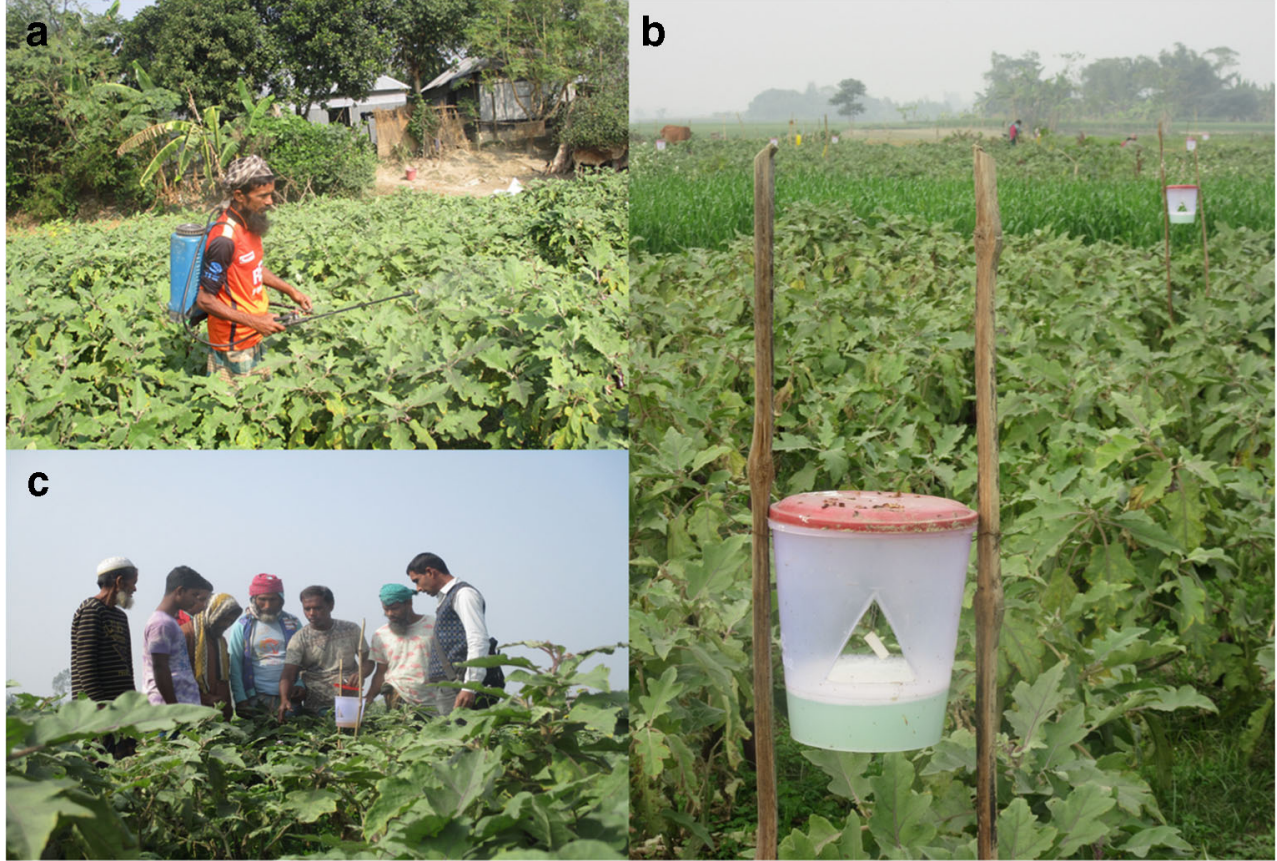

farmers' and consumers' health and pollutes the environment (Pimentel 1995; Miah et al. 2014). Indeed, insecticide residues above the maximum residue limits have been detected in eggplants (Chowdhury et al. 2013). Overuse of insecticides also leads to the development of insecticide resistance and kills non-target insects, including natural enemies (Ruberson et al. 1998), resulting in reduced natural pest control. Therefore, eggplant growers need environmentally benign and cost-effective alternatives to broad-spectrum insecticides.

One alternative is to use sex pheromone-based mass trapping. Pheromones are species specific, active in small amounts, nontoxic to vertebrates, beneficial insects, and the environment, and leave no residues on the produce (El-Sayed et al. 2006; Witzgall et al. 2010). Moreover, the small chance of developing pheromone resistance makes it a long-term option for pest control (Witzgall et al. 2010). Pheromone-based practice has been reported to provide efficient management of various Lepidopteran pest species (El-Sayed et al. 2006; Witzgall et al. 2010). Insecticidal control of Lepidopteran borers is difficult, as caterpillars live inside plants, whereas pheromones target the adults, which live outside plants. Moreover, pheromone trapping could support the timing of targeted additional spraying, limiting insecticide use (Cruz et al. 2012). ESFB female sex pheromones have already been identified and synthetically produced (Zhu et al. 1987), and the efficacy of blends of two major components, (E)-11hexadecenyl acetate (E11-16:Ac) and (E)-11-hexadecen-1ol (E11-16:OH), has been tested to suppress the male moth population (Cork et al. 2001).

Another alternative to broad spectrum insecticides is to use so-called biorational insecticides because these have limited or no effect on non-target organisms including natural enemies, birds, and mammals and are therefore considered environmentally friendly (Sarfraz et al. 2005; Rosell et al. 2008). Spinosad, originating from the soil bacterium Saccharopolyspora spinose, is considered an ideal candidate for incorporation in integrated pest management (IPM) because of its selective toxicity and favorable environmental profile (Bret et al. 1997; Sarfraz et al. 2005; Biondi et al. 2012). Spinosad is primarily a stomach poison with some contact, systemic, and transcellular activity and is active especially against a range of Lepidopteran insects and some Diptera, Coleoptera, and Thysanoptera (Bret et al. 1997; Williams et al. 2003). Spinosad is effective against various borers including ESFB (Kalawate and Dethe 2012). However, integration in trap catch-based applications has to our knowledge not yet been attempted in eggplant.

The Asian Vegetable Research and Development Centre (AVRDC) developed and promoted an IPM strategy for ESFB control for South Asia, including Bangladesh, in 2000-2006 (Alam et al. 2006; Srinivasan 2008). This package was based on sanitation through regular removal of infested shoots and fruits, refraining from insecticides, and installing pheromone traps. A national IPM policy was launched in Bangladesh in 2002, and extension staff were trained to train farmers through IPM farmers' field schools. Despite these efforts, farmers continue to use pesticides and IPM adoption remains low, a phenomenon often observed, particularly in developing countries (Morse and Buhler 1997; Peshin 2013; Parsa et al. 2014). According to Parsa et al. (2014), globally, institutional problems, weak adoption incentives, and outreach problems are important factors limiting adoption. In 
South and South-East Asia, it is mainly weaknesses in IPM and in IPM research and outreach that limit adoption. IPM is labor-intensive, and IPM research does not focus on farmers' needs and lacks participatory approaches (Parsa et al. 2014). Furthermore, IPM research is often focused on technical efficacy, overlooking practical implementation efficacy for target farmers. Moreover, low profitability and high risk or uncertainty are often considered obstacles to IPM adoption (Morse and Buhler 1997; Peshin 2013). A further likely factor for poor adoption is that the major focus in an IPM strategy is on a single major pest rather than on all pests that farmers would like to control (Horne et al. 2008). For example, in Bangladesh, a major production constraint or risk alongside ESFB is bacterial wilt, which can lead to $20-70 \%$ plant loss (Nahar et al. 2019). Therefore, it is important to analyze IPM profitability for ESFB across a range of bacterial wilt levels. Finally, farmers' knowledge level should be considered as a potential constraint to adoption (Litsinger et al. 2009; Peshin 2013; Wyckhuys et al. 2019).

In the present study, we designed experiments together with farmers using available IPM components (pheromone trap, sanitation, biorational insecticide) and compared these improved management options with farmers' conventional practices and no control as reference treatments. This allowed us to assess the technical performance of tested packages for ESFB management, including effects on other pests and natural enemies, and to separately analyze economic viability and practical applicability, taking implementation aspects as possible underlying reasons and rationales for farmers to reject, adopt, or adapt them.

\section{Materials and methods}

\subsection{Study site and farmer selection for the participatory study}

A participatory study on IPM of ESFB was carried out by the first author in Pirijpur village $\left(25^{\circ} 02^{\prime} 13^{\prime \prime} \mathrm{N}-89^{\circ} 50^{\prime} 08^{\prime \prime} \mathrm{E}\right)$, Jamalpur district, the major eggplant growing area of Bangladesh, located in the so-called Old Brahmaputra floodplain. Farmers cultivate eggplants during the cool dry season (Rabi season: September-March). The steps taken to select the study village and participating farmers were as follows: (i) focus group discussion with farmers from different upazillas (administrative areas), agricultural officers, scientists from the regional agricultural research station, and NGO representatives, introducing the study and seeking advice on villages worth investigating and (ii) transect walks with local extension agents through five villages from two upazillas to assess eggplant cultivation constraints and farmers' interest in research. On the basis of acreage of eggplant cultivation, farmers' interest in getting involved, and accessibility (transport), three villages were shortlisted. After a visit by the first and the last author, Pirijpur was finally selected. In a first formal meeting, the extension agent then formally introduced the first author, who explained the objective of the study and invited farmers to participate in it.

In subsequent village meetings, farmers were selected based on their enthusiasm to join the study, and treatments to be included in the study were negotiated. Besides the initial meeting, monthly meetings were held with participating farmers to understand their view on the research (Fig. 1c). At the end of the experimentation, results were discussed with these farmers. There were also frequent interactions with participating and other curious neighboring farmers during the field work. These discussions were used to assess the practical implementation aspects from farmers' perspectives and possible constraints.

\subsection{Treatment negotiation and experimental design}

The choice of treatments was based on a combination of what the literature indicated as promising as suggested by the first author and what farmers considered as feasible and worth testing. Treatments were negotiated again for year 2 based on year 1 outcomes and insights gained.

\subsubsection{Year $1(2015-2016)$}

Eight farmers participated in the year 1 study. Testing of pheromone trapping (mass trapping through a female sex pheromone lure) either alone or with sanitation (removal of infested shoots and fruits at weekly intervals) was proposed as potential improvements on current farmer management. Six farmers instantly rejected sanitation as too laborious and complex; two farmers started but after 1 week dropped it for the aforesaid reasons. Farmers were reluctant to implement pheromone trapping alone, as they considered it risky. Farmers proposed combining trapping with insecticide spraying. Trap-based biorational spraying was then proposed, and advantages of pheromone trapping and biorationals were discussed in terms of reduced impact on natural enemies, farmers' health, and the environment. Farmers insisted on also testing conventional spraying while trapping. Consequently, the following treatments were tested by each farmer on his/her fields: (i) pheromone trapping alone, (ii) pheromone trapping combined with trap-based biorational spraying, (iii) pheromone trapping combined with bi-weekly conventional insecticide spraying, (iv) farmers' conventional weekly spraying, and (v) untreated control (for details see below).

Replicates were allocated over the landscape depending on the farmers' land availability. To minimize interference among treated plots and with surrounding fields not included in this study, two rules were applied in allocating treatments to the plots: (1) all participating farmers contributed one plot for 
each of the five treatments and (2) treatments with and without traps were applied in different fields belonging to the same farmer and as far from one another as possible, at a minimum distance of $100 \mathrm{~m}$. Per farmer, treatments with traps were located as close to one another as possible, preferably in one field divided into 2-3 treatment plots. In the final layout, fields with pheromone traps formed two clusters, each containing plots of four different farmers, at a distance of $330 \mathrm{~m}$. Thus, the field with pheromone traps formed two networks of nearby plots. Sizes of the pheromone trap-treated plots varied from 400 to $600 \mathrm{~m}^{2}$; farmers' practice plots varied from 256 to $600 \mathrm{~m}^{2}$. Untreated control plots were set at $16 \times 16 \mathrm{~m}$ to minimize loss of harvest for the farmers. It was agreed that any harvest losses would be compensated.

Soon after transplanting, a single pheromone trap (a plastic container with two opposite triangular openings where a layer of water could be kept in the bottom (Ispahani Biotech, Bangladesh) (Fig. 1b)) was installed in four farmers' fields to monitor moth appearance, observed around 30 days after transplanting (DAT). The number of traps then installed varied according to the size of the trap-treated area, with a minimum of four traps per treatment installed in a $10 \times 10 \mathrm{~m}$ grid, $5 \mathrm{~m}$ from all borders. The traps were mounted on bamboo poles and suspended $10 \mathrm{~cm}$ above the plant canopy. A 4.5$\mathrm{cm}$ layer of water mixed with detergent powder $(0.25 \% \mathrm{w} / \mathrm{v})$ was maintained in the trap. The lure made up of a polyethylene vial impregnated with $0.1 \mathrm{ml}$ of a hexane solution containing $3 \mathrm{mg}$ of $(97 \% \mathrm{w} / \mathrm{w})(\mathrm{E})-11$-hexadecenyl acetate (E1116:Ac) and (E)-11-hexadecen-1-ol (E11-16:OH) was hung from the plastic lid of the trap by a metal wire, so the lure remained in the middle between the triangular openings of the trap (Fig. 1b). Traps were installed jointly with farmers keeping the triangular openings north and south facing to minimize water evaporation. Lures were replaced every 4 weeks, and farmers changed the water weekly, supervised by the researcher who simultaneously collected moths for counting.

The biorational insecticide Tracer 45 SC (Spinosad) was sprayed at a concentration of $0.4 \mathrm{~mL} / \mathrm{L}$ of water $(200 \mathrm{~mL} / \mathrm{ha})$ between 8.00 and 11.00 h using a knapsack sprayer. The spray date was guided by the researcher based on trap counts and ESFB lifecycle information. Given the reported lifecycle of the moth (Srinivasan 2008), a first peak of adult moths was expected 1 month after the moth's first appearance in the study area. Trap catches showed substantial increase in the population indeed around 1 month from first catches, and spraying was carried out within a week of the observed increase, taking into account the time needed for egg laying and hatching of 1 st instar caterpillars. Subsequent sprays were planned at around 1-month intervals from the first spray. Trap catches were still monitored to assess the next peak in population density, and it was decided that spraying should be carried out when at least on average 4 moths/trap/week were observed. Thus, first spraying occurred at 64 DAT (4 moths/ trap/week) and subsequent spraying at 94 DAT (4 moths/ trap/week), $130 \mathrm{DAT}$ (10 moths/trap/week), and $159 \mathrm{DAT}$ (15 moths/trap/week), respectively. Although the rationale for timing spraying based on trap catches was discussed with the farmers, it was difficult for farmers to understand. Therefore, in negotiations about the timing of conventional insecticide spraying in combination with trapping, it was decided to apply the first spraying together with the first trapbased biorational spraying at 1 month after the first moths were observed and thereafter at roughly 15-day intervals. Farmers thus sprayed conventionally at 64, 79, 94, 111, 130, 146, and 159 DAT. All fields showed a similar pattern of population dynamics, as the fields were close to one another. Therefore, spraying was carried out on the same day for all replicates. In farmer-managed plots, the insecticides chlorpyrifos (48 EC), cypermethrin (10 EC), and malathion (57 EC), alone or in cocktails, were applied weekly at a concentration of each $1.5 \mathrm{~mL} / \mathrm{L}$ of water $(760 \mathrm{~mL} / \mathrm{ha})$ from $20 \mathrm{DAT}$ to the end of the season. The actual dates on which farmers sprayed were recorded.

\subsubsection{Year 2 (2016-2017)}

Nine farmers participated in year 2, seven from the year 1 study, and two new farmers. On the basis of the year 1 study, farmers suggested dropping the combination of trapping with conventional spraying as this treatment did not increase yield but killed natural enemies. Fields with pheromone trapping formed three clusters at a distance of 115-130 m. Except for this change, the research protocol of year 2 was as in year 1 . Based on the same rationale as for year 1, biorational spraying was carried out at 71, 107, 138, and 163 DAT. Farmers sprayed conventionally weekly, as in year 1 . Pheromone treatment plots varied from 400 to $600 \mathrm{~m}^{2}$; farmers' practice plots varied from 256 to $760 \mathrm{~m}^{2}$. Untreated control plots were set at $16 \times 16 \mathrm{~m}$ to minimize loss of harvest for the farmers.

\subsection{Observations and analyses}

Observations were made in the center of treatment plots at a minimum $5 \mathrm{~m}$ distance from all borders in a $5 \times 5 \mathrm{~m}$ plot within each treatment plot in year 1 and in a $4 \times 4 \mathrm{~m}$ plot in year 2 . Henceforth, these plots are referred to as observation plots to distinguish them from the (larger) treatment plots. The initial number of plants was recorded in each observation plot; plant loss due to bacterial wilt was also recorded, and lost plants were compensated by including plants from rows directly adjacent to the observation plot, thereby gradually increasing the area of the observation plot but keeping a distance from all borders of at least $4 \mathrm{~m}$. From this area, a theoretical total yield and a marketable yield were calculated as if there had been no plant lost to bacterial wilt. Data on plant loss to bacterial wilt were analyzed, and no difference between 
treatments was found (data not shown). Individual plots differed in level of bacterial wilt though, and, to analyze the pure ESFB effect, a total yield and a marketable yield at the observed average plant loss to bacterial wilt across replicates (27\% in year 1 and $29 \%$ in year 2) are reported.

\subsubsection{Shoot infestation}

Observation plots were monitored weekly to assess initiation of shoot infestation. Shoot infestation data were recorded at 10-day intervals from onset (39 DAT) until it stopped (113 DAT). Thirty randomly picked plants from an average of 55 plants were monitored, ensuring that plants from each row of the observation plot were represented, to count the number of infested shoots. Shoots that were wilted, had holes, or had frass attached were considered infested. A further five random plants per replicate were taken to count the total number of shoots per plant. This was extrapolated to the number of shoots in the sample of 30 plants. Ultimately, the percentage infestation was calculated from the total and the infested number of shoots of 30 plants.

\subsubsection{Fruit infestation and yield}

Eggplants were harvested weekly from observation plots. Healthy and infested eggplants were weighed using a digital scale. Any fruits with holes, frass attached, or a secondary infection (sign of rotting) were considered infested. The percentage of infested fruits was calculated per observation day and plot, and these data were combined in the cumulative infestation.

\subsubsection{Production costs}

Farmers' crop protection activity, the tested potential improved management activities, and material and labor input were recorded. Costs of inputs and sales prices of fruits were also recorded. Sales prices of fruits were used to assess normal average income per kilogram fruit and income per kilogram fruit under low price conditions. Costs of production were considered to include the total costs of all material inputs and hired labor (fertilizers, crop protection products, irrigation, hire of equipment, and labor for tillage) and the labor for crop protection. Labor for crop protection was accounted for separately as this varies with treatments. The own labor for standard practices not related to crop protection such as transplanting, weeding, and harvesting was not included in total production costs. Income from all treatments was calculated separately for normal or low sale prices as follows:

$$
\begin{aligned}
\text { net income }_{i, y}\left(€ \mathrm{ha}^{-1}\right)= & \text { marketable yield }_{i, y}\left(\mathrm{t} \mathrm{ha}^{-1}\right) \\
& \times \text { price }\left(€ \mathrm{t}^{-1}\right)-\operatorname{cost}_{i}\left(€ \mathrm{ha}^{-1}\right)
\end{aligned}
$$

where subscripts $i$ and $y$ refer to treatment and year, respectively. To assess risks for the different treatments relating to observed variability in bacterial wilt losses between years and fields, the breakeven points for investment in different ESFB control strategies and ranges of bacterial wilt were calculated in two steps. Based on a theoretical yield, if no plants had been lost to bacterial wilt and a fraction of plants that were lost to bacterial wilt, the net income at any fraction of wilted plants (net income with wilt) is defined by the following:

$$
\begin{aligned}
& \text { net income with wilt } \mathrm{i}_{i, y}\left(€ \mathrm{ha}^{-1}\right) \\
& =\text { theoretical yield }_{i, y}\left(\mathrm{t} \mathrm{ha}^{-1}\right) \\
& \quad \times(1-\text { fraction wilted plants }) \\
& \quad \times \text { price }\left(€ \mathrm{t}^{-1}\right)-\text { cost }_{i}\left(€ \mathrm{ha}^{-1}\right)
\end{aligned}
$$

where subscripts $i$ and $y$ have the same meaning as above. The net income with wilt at breakeven point is defined as zero, hence at breakeven point:

$$
\begin{aligned}
& \text { theoretical yield }{ }_{i, y}\left(\mathrm{t} \mathrm{ha}^{-1}\right) \times(1 \text {-fraction wilted plants }) \\
& \quad \times \text { price }\left(€ \mathrm{t}^{-1}\right) \\
& =\operatorname{cost}_{i}\left(€ \mathrm{ha}^{-1}\right)
\end{aligned}
$$

The percentage of wilted plants at breakeven point for each treatment $i$ in year $y$ can then be calculated as follows:

$$
\begin{aligned}
& \text { \%wilted plants } \\
& \times, y \\
& \times\left\{1-\left[\operatorname{cost}_{i, y}\left(€ \mathrm{ha}^{-1}\right)\right] /\left[\text { theoretical yield }_{i, y}\left(\mathrm{t} \mathrm{ha}^{-1}\right) \times \text { price }\left(€ \mathrm{t}^{-1}\right)\right]\right\}
\end{aligned}
$$

\subsubsection{Moth counts}

Every week, the numbers of male moths caught per trap per plot were counted. When trapped moths were few, all moths were handpicked by forceps, counted, and discarded. When there were many moths, the water from the trap was poured on muslin cloths, and moths were counted. Traps that were less than $3 \mathrm{~m}$ distance from sprayed plots were eliminated from analysis.

\subsubsection{Counts of natural enemies and sucking insect pests}

Per treatment plot, one yellow sticky trap $(25 \times 10 \mathrm{~cm}$, Horiver, Koppert, Netherlands) was suspended from a bamboo stick $15 \mathrm{~cm}$ above the plant canopy. Sticky traps were changed weekly. Removed sticky traps were carefully wrapped in a transparent, thin polythene sheet and brought to the laboratory for identification to genus level and counting of natural enemies and sucking insects. The number of a 
selection of natural enemies (ladybird beetle, Trichogramma spp., Bracon spp.) and sucking insects (aphids and jassids) was counted under a magnifying glass and a stereo microscope from 4 of 8 squares on each sticky trap.

\subsubsection{Statistical analyses}

Data were tested for normality and homogeneity of variances using Shapiro-Wilk's and Levene's tests. Only the percentage of fruit infestation and the yield data met these assumptions. These were analyzed using a standard analysis of variance with post hoc mean separation according to Tukey, using Genstat version 18.0. For all insect counts and percentage shoot infestation, distributions were found non-normal, and therefore models using Poisson, zero-inflated Poisson, and negative-binomial distributions were compared. Given Akaike's information criterion, data on the percentage of shoot infestation and ladybird beetle were found to be best analyzed using a Poisson distribution, whereas Trichogramma spp., Bracon spp., aphids, jassids, and male moths were best analyzed using a negative binomial distribution. These analyses were conducted in $\mathrm{R}$ version 64 3.6.1 using the packages: "glmmTMB," "ggplot2," "Rmisc," "MASS," "lsmeans," and "Imtest."

\section{Results and discussion}

The present study aimed to test a number of improved practices for the integrated management of eggplant shoot and fruit borer (L. orbonalis, ESFB), together with smallholder eggplant farmers, to separately analyze the technical efficacy, economic viability, and practical applicability of these practices and assess the chance of adoption. In brief, pheromone trapping alone reduced shoot and fruit infestation and increased marketable yield and income compared with current farmers' practice (Fig. 2a, b, c, and d; Table 1). Combining pheromone trapping with trap-catch-based spraying of the biorational Spinosad provided further reduction of shoot and fruit infestation, and increased farmers' marketable yield and income. Farmers' practice neither reduced infestation nor increased yield. However, compared with the untreated control, it drastically reduced natural enemies: predatory ladybird beetles (Coccinella septempunctata, Harmonia axyridis, Menochilus sexmaculatus) and parasitoids (Trichogramma spp. and Bracon spp.). In contrast, pheromone trapping alone or with biorational insecticides did not affect natural enemies compared with the untreated control. Limited use of biorational insecticides reduced jassids (Amrasca biguttula biguttula) and aphids (Aphis gossypii) comparably with the more frequent conventional insecticide application under farmers' practice, whereas these pest populations were comparable and higher with pheromone trapping alone and in the untreated control. In terms of economic feasibility, pheromone trapping alone required less labor and cash input than farmers' practice. Adding biorational insecticide slightly increased costs compared with farmers' practice but increased income more. While experimenting, farmers rejected two IPM components: (i) removal of infested shoots and fruits at regular intervals because it was too labor demanding and (ii) combining conventional insecticides with trapping because in this case, they argued insecticide did not reduce ESFB while costing money and reducing natural enemies. During joint experimentation, discussing with farmers formally and interacting with them in the fields, we found that farmers had difficulty understanding the ESFB lifecycle and the pheromone trapping mechanism.

Below, an elaboration follows along the same lines: (i) technical efficacy, (ii) economic viability, and (iii) practical applicability of the tested improved IPM.

\subsection{Technical efficacy of the tested IPM}

\subsubsection{Shoot and fruit infestation}

Shoot infestation started around 40 DAT (days after transplanting) and continued up to 100-115 DAT (Fig. 2). From the onset of fruiting (60 DAT), caterpillars switched to fruit infestation, and this increased up to final harvest (185 DAT).

In both years, the two-way interaction between pest management and observation dates on percentage shoot infestation was significant $(p<0.001)$, as differences between treatments were limited, when overall infestation levels were low before 60 DAT and after 80 DAT (year 1) to 100 DAT (year 2) (Fig. 2a, b). When shoot infestation levels were higher, the effect of pest management treatments became significant. Pheromone traps kept shoot infestations below 3 (year 1) to $6 \%$ (year 2), roughly half the levels observed under farmers' practice. The addition of conventional spraying to pheromone trapping tested in year 1 did not provide additional control; the addition of limited biorational spraying provided a slight but significant additional control in both years during peak infestation. Compared with not spraying at all, the farmers' practice of regular spraying did not provide any significant control except in year 2 at 95 DAT when a limited control of 5 percentage point lower shoot infestation was observed compared with the untreated control (14\% versus 19\%) (Fig. 2a, b).

In both years, the interaction between pest management and observation dates on fruit infestation was also significant $(p<0.001)$. Improved management provided better protection (10-58 percentage point lower fruit infestation) throughout the whole fruiting period (60-185 DAT) compared with farmers' conventional spraying (Fig. 2c, d). At the peak fruiting period (90-150 DAT), improved practices reduced fruit infestation by $28-44$ percentage point compared with 

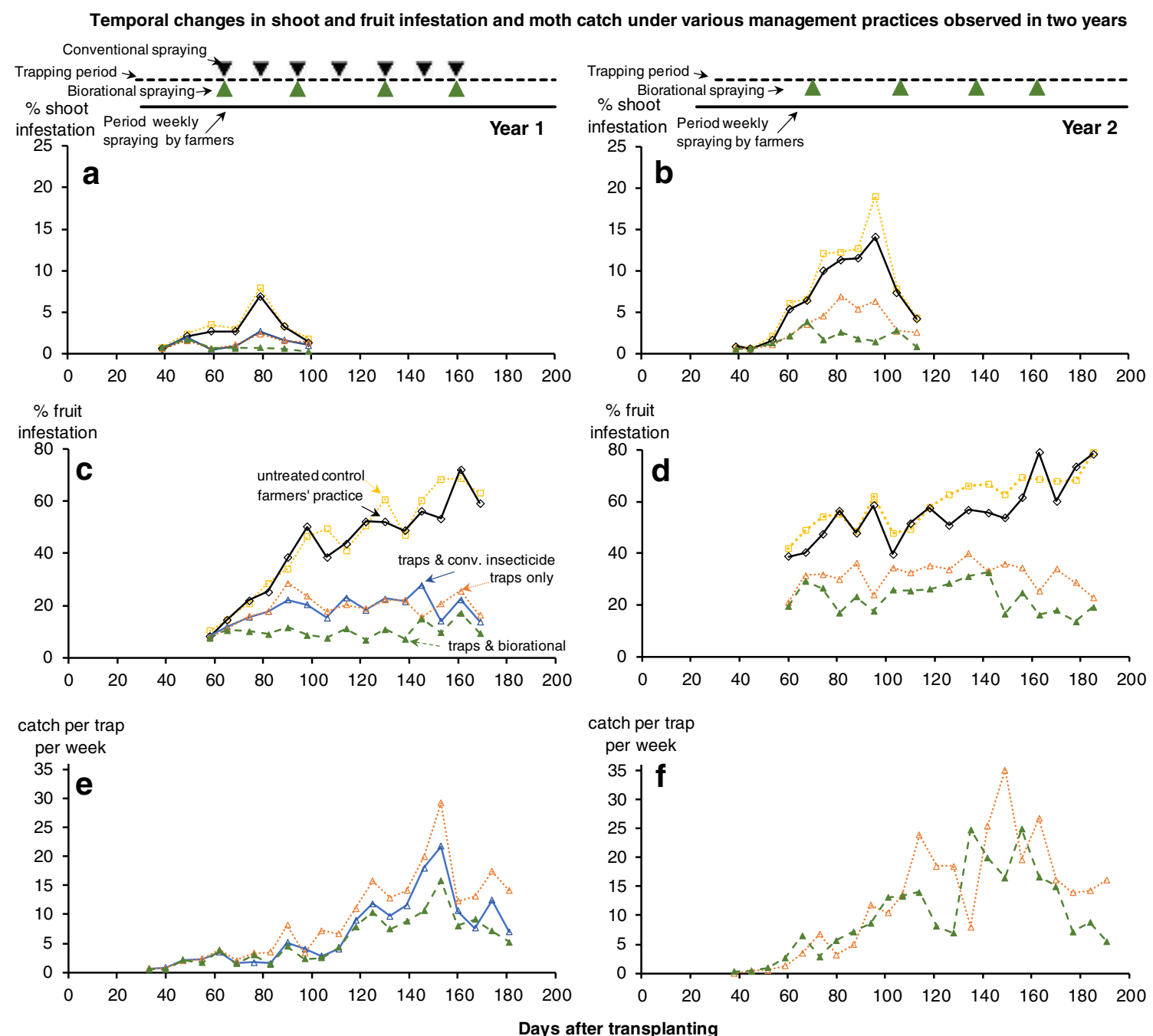

Fig. 2 Percent shoot $(\mathbf{a}, \mathbf{b})$ and fruit (c, d) infestation and number of trapped male moths $(\mathbf{e}, \mathbf{f})$ over the two experimental seasons, moth counts only where traps were installed. Periods of trapping and farmers' practice spraying and the days of biorational and conventional spraying (latter year 1 only) are indicated per year at the top of the figure. At most

dates, infestations were higher for the untreated control and farmers' practice plots than for the plots where traps were installed. Trapping alone or with conventional spraying (year 1 only) showed comparable infestation, and this was mostly higher than trapping accompanied by spraying biorational insecticides

farmers' practice. The addition of conventional spraying to pheromone trapping did not provide additional control; hence, farmers proposed dropping this treatment in the second year. However, adding biorational insecticide spraying to pheromone trapping provided an additional reduction in infestation (9-15 percentage point). Compared with the untreated control, the weekly spraying under farmers' practice did not systematically reduce infestation; under farmers' practice, only at two to three random dates was a limited reduction in fruit infestation by $2-12$ percentage point observed in both years (Fig. 2c, d).

The notable difference in effect on ESFB infestation between the 18 to 21 times spraying under farmers' practice and the 4 times biorational application (Fig. 2) is most likely caused by a combination of factors, including the very short period between hatching and the 1st instar larvae entering shoots or fruits (Hanur et al. 2014), which provided a very narrow margin for control by the applied contact insecticides. Biorational spraying targeted the peak numbers in this life stage. Furthermore, insects might have developed resistance due to repeated insecticide use (Alam et al. 2006; Srinivasan 2008; Rahman and Rahman 2009). The trap-catch-based spraying of the biorational optimally targeted an expected peak in eggs and 1st instar larvae, as the applied Spinosad generally also kills the insect through contact and ingestion, although local systemic action through transcellular movement has also been reported (Williams et al. 2003; Van Leeuwen et al. 2005; Weintraub and Mujica 2006). Spinosad affected the moth population locally because the number of moths per trap per week was reduced in Spinosad-treated plots compared with the adjacent plots with 
Table 1 Economic assessment of different integrated pest management strategies and farmers' practice against eggplant shoot and fruit borer (Leucinodes orbonalis) and an untreated control. Prices in local currency $(\mathrm{TK})$ are converted based on $1 €=\mathrm{TK} 84.7$, the average conversion over the years 2015-2017

\begin{tabular}{|c|c|c|c|c|c|c|c|c|c|c|}
\hline \multirow[t]{2}{*}{ Treatments } & \multirow[t]{2}{*}{$\begin{array}{l}\text { Expenses } \\
(€ / \text { ha })^{\mathrm{i}}\end{array}$} & \multirow[t]{2}{*}{$\begin{array}{l}\text { Marketable yield } \\
(\mathrm{t} / \mathrm{ha})\end{array}$} & \multicolumn{2}{|c|}{ Sales income (€/ha) } & \multicolumn{2}{|c|}{ Net income $(€ /$ ha) } & \multicolumn{2}{|c|}{$\begin{array}{l}\text { Additional income } \\
\text { over farmers' } \\
\text { practice }(€ / \text { ha) }\end{array}$} & \multicolumn{2}{|c|}{$\begin{array}{l}\text { Percentage wilt at } \\
\text { breakeven }\end{array}$} \\
\hline & & & $\begin{array}{l}\text { Normal }{ }^{i \mathrm{i}} \\
\text { price }\end{array}$ & $\begin{array}{l}\text { Low }{ }^{\mathrm{iii}} \\
\text { price }\end{array}$ & $\begin{array}{l}\text { Normal } \\
\text { price }\end{array}$ & $\begin{array}{l}\text { Low } \\
\text { price }\end{array}$ & $\begin{array}{l}\text { Normal } \\
\text { price }\end{array}$ & $\begin{array}{l}\text { Low } \\
\text { price }\end{array}$ & $\begin{array}{l}\text { Normal } \\
\text { price }\end{array}$ & $\begin{array}{l}\text { Low } \\
\text { price }\end{array}$ \\
\hline \multicolumn{11}{|l|}{ Year 1} \\
\hline Pheromone + biorational & 1557 & $33.2 \mathrm{a}^{\mathrm{iv}}$ & 4481 & 2920 & 2924 & 1363 & 1694 & 1087 & 75 & 61 \\
\hline Pheromone + conventional & 1507 & $28.7 \mathrm{~b}$ & 3878 & 2527 & 2371 & 1020 & 1140 & 744 & 71 & 56 \\
\hline Only pheromone & 1331 & $28.9 \mathrm{~b}$ & 3902 & 2543 & 2571 & 1212 & 1341 & 936 & 75 & 62 \\
\hline Farmers' practice & 1509 & $20.3 \mathrm{c}$ & 2740 & 1785 & 1231 & 276 & 0 & 0 & 60 & 38 \\
\hline Untreated control & 1057 & $19.9 \mathrm{c}$ & 2693 & 1755 & 1636 & 698 & 405 & 422 & 71 & 56 \\
\hline \multicolumn{11}{|l|}{ Year 2} \\
\hline Pheromone + biorational & 1576 & $31.2 \mathrm{a}$ & 4208 & 2742 & 2632 & 1166 & 1877 & 1224 & 74 & 60 \\
\hline Only pheromone & 1348 & $26.3 \mathrm{~b}$ & 3549 & 2312 & 2201 & 964 & 1446 & 1023 & 73 & 59 \\
\hline Farmers' practice & 1580 & $17.3 \mathrm{c}$ & 2335 & 1521 & 755 & -59 & 0 & 0 & 52 & 27 \\
\hline Untreated control & 1060 & $16.7 \mathrm{c}$ & 2251 & 1467 & 1191 & 407 & 436 & 465 & 67 & 49 \\
\hline
\end{tabular}

${ }^{\mathrm{i}}$ Expenses include all costs of material inputs over the season and labor for crop protection, but not labor for other crop management practices

${ }^{i i}$ In a normal price period, eggplant sells @ 135€/t (averaged over harvesting months and years of study)

iii In a low price period, eggplant sells @ 88€/t (averaged over last 5 years as assessed from farmers' interviews)

${ }^{\text {iv }}$ Values per year within a column followed by the same letter did not differ significantly $(p>0.05)$ according to Tukey's HSD test

only pheromone traps or with conventional insecticide spraying (Fig. 2e, f).

\subsubsection{Populations of ESFB male moths, natural enemies, and sucking insects}

For insect counts (ESFB moths, natural enemies, and sucking insects), the interaction between pest management treatments and observation dates was significant $(p<0.001)$ in half of the cases; when the interaction was not significant, both time and treatment effects were. When significant, the interactions were always the consequence of no significant differences when few insects of a species were observed; when a species was more abundant, differences were always significant. In both years, adding biorational spraying to pheromone trapping significantly reduced the peak numbers of male ESFB moths compared with pheromone trapping alone (Fig. 2e, f). The conventional spraying at times also reduced the moth populations slightly (Fig. 2e, f), but this did not translate into lower fruit infestations or higher yield, as reported above. The dynamics over time in male moth catches are obviously only available from pheromone-trapped plots. The population built up from nearly 90 DAT (December) and gradually increased up to 170 DAT (March). A first peak in the population was end of December at 90 DAT, roughly 1 month after the first appearance had been observed and thereafter again at 1-month intervals: 130 DAT (end of January), 150 DAT (end of February), and 170 DAT (end of March) for both study years (Fig. 2e, f). This corresponds more or less to the reported 1month lifecycle (Srinivasan 2008).

In both years, on most observation dates, the numbers of the observed predatory ladybird beetle complex (Coccinella septempunctata, Harmonia axyridis, Menochilus sexmaculatus) and parasitoids (Trichogramma spp. and Bracon spp.) were drastically reduced in farmers' practice plots compared with plots with pheromone trapping alone or combined with biorational spraying (Fig. 3). When conventional insecticide was sprayed on pheromone-trapped plots, a substantial reduction in all natural enemies was also observed, and numbers of natural enemies on these plots were comparable with numbers on farmers' practice plots. In contrast, the initial drop in the number of natural enemies after biorational spraying was always followed by a population recovery within 1 to 2 weeks. Numbers of natural enemies in pheromone-only-trapped plots were comparable with those in untreated control plots. The observed effects are in line with a study by Hill et al. (2017) reporting that organophosphates, particularly chlorpyrifos, drastically reduced arthropod natural enemy densities in the field. Even one or two applications in year 1 in plots combining the conventional insecticide with pheromone trapping largely 


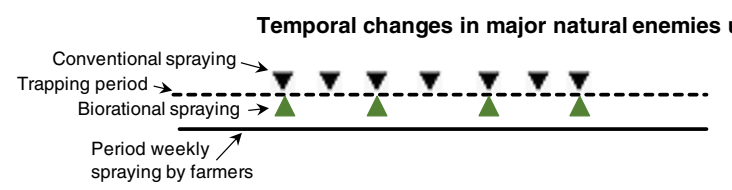

number of ladybird beetles per trap per week Year 1: Ladybird beetles

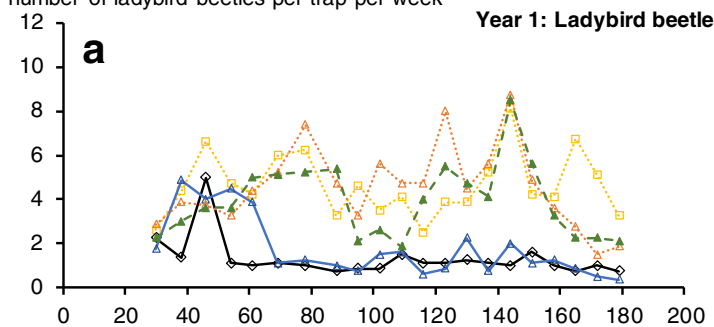

number of Trichogramma spp. per trap per week

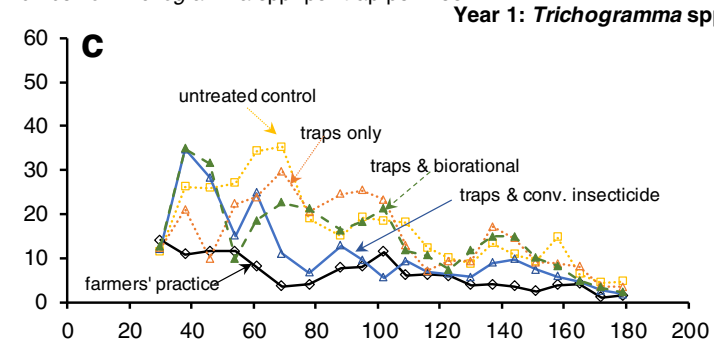

number of Bracon spp. per trap per week

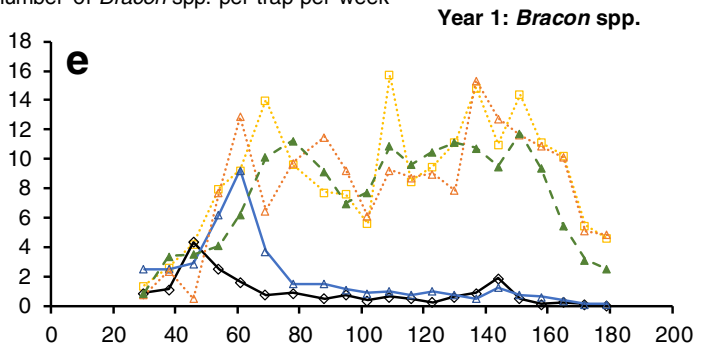

Days after transplanting

Trapping period $\rightarrow$

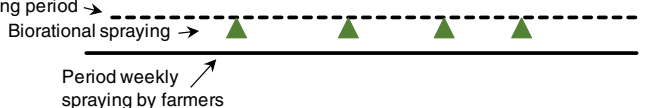

spraying by farmers

number of ladybird beetles per trap per week ${ }^{12}$ Year 2: Ladybird beetles

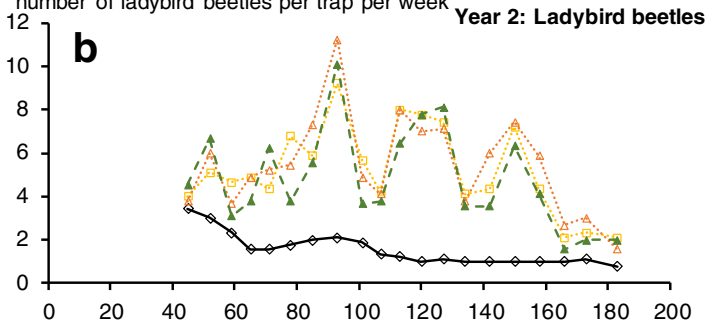

number of Trichogramma spp. per trap per week

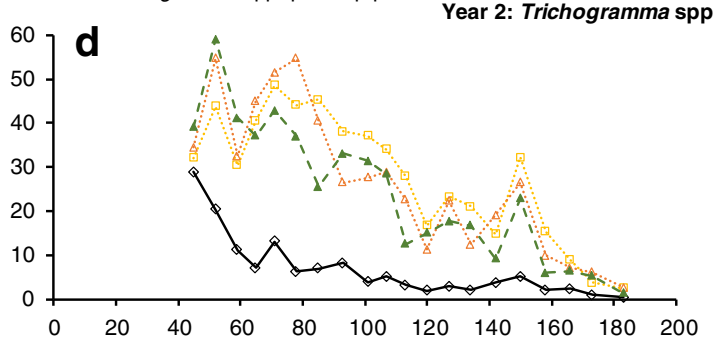

number of Bracon spp. per trap per week

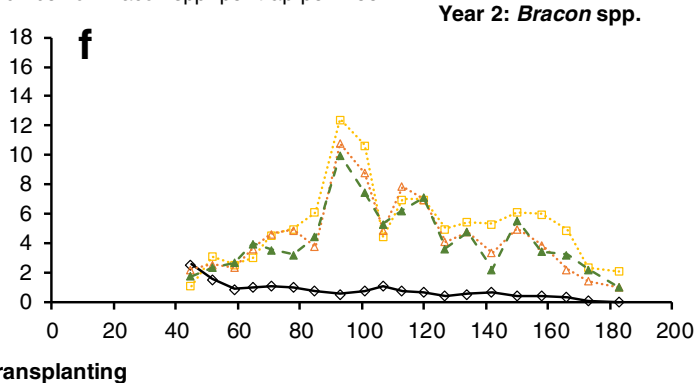

dates, numbers of natural enemies were lower for the farmers' practice plots and plots where conventional insecticide spraying was combined with pheromone traps than for plots that were not sprayed or where the biorational insecticide was sprayed

mostly not harmful to predators, especially Coleopterans (Williams et al. 2003; Galvan et al. 2005), although other studies reported that Spinosad reduced the number of parasitoids (reviewed in Biondi et al. 2012).

In both years, the populations of sucking insect complexes-jassids (mainly Amrasca biguttula biguttula) and aphids (mainly Aphis gossypii)—remained lowest in plots where pheromone traps were combined with limited use of biorational insecticides (Fig. 4). Farmers' practice limited these sucking insect species to levels comparable with those for biorational spraying. Numbers observed in untreated control plots and pheromone-only-trapped plots were highest and comparable (Fig. 4). Our data do not allow assessment of whether these levels of jassids and aphids reduced yield. If sucking insects develop beyond this level, they might have Spodoptera exigua, and studies reporting Spinosad to be 

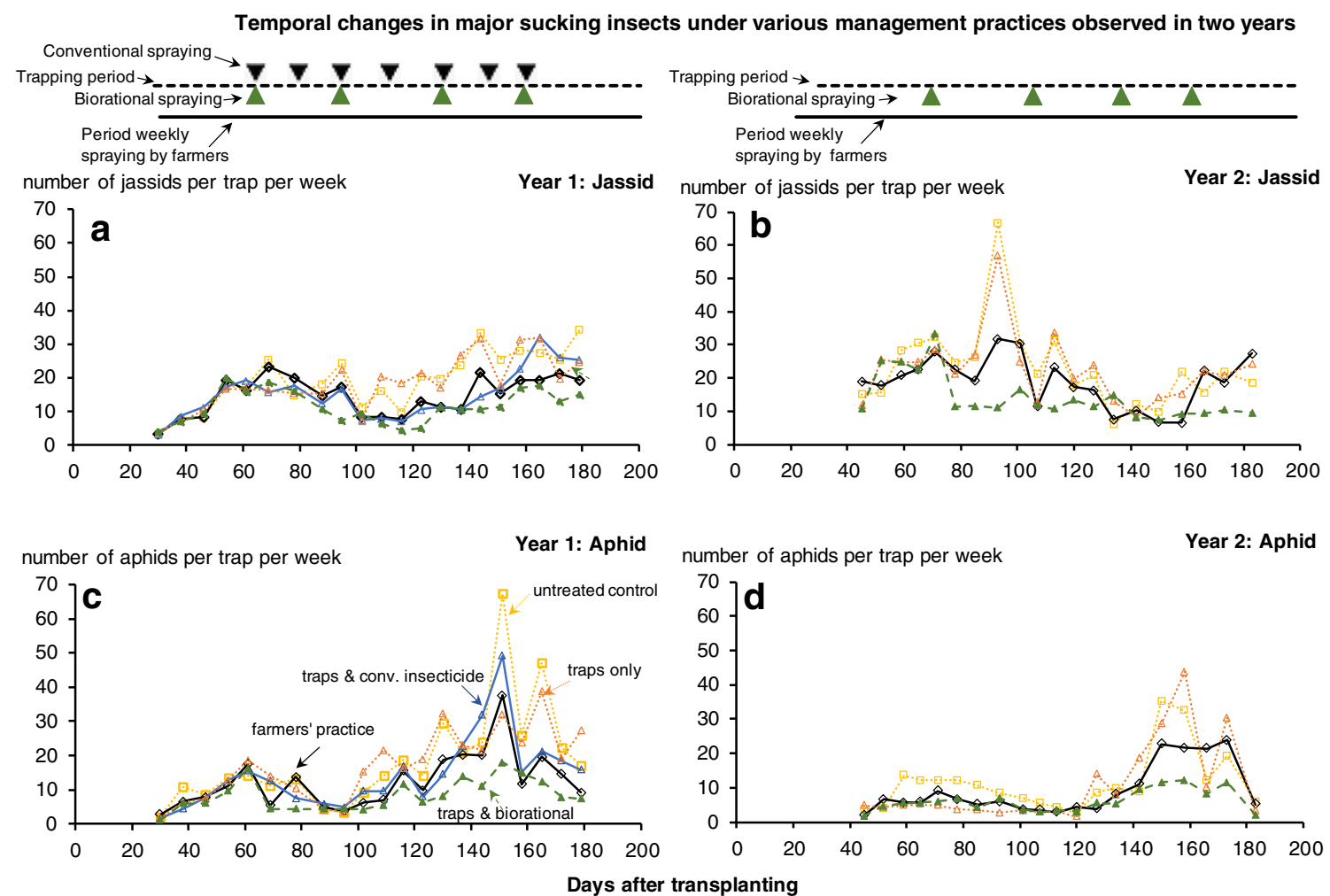

Fig. 4 Numbers of the two major sucking insects, jassids (a, b), and aphids (c, d) trapped by sticky traps per week over the two experimental seasons. Periods of trapping and farmers' spraying practice and the days of biorational and conventional spraying (latter year 1 only) are indicated per year at the top of the figure. Numbers of

major sucking insects were lower on most dates for plots where the biorational insecticide was sprayed than for plots that were not sprayed or where only traps were used. Farmers' conventional spraying also reduced their numbers on some dates

higher impact on yield; in that case, farmers may revert to using insecticides in addition to trapping. This reversion to spraying could be a pitfall of IPM. In the present study, adding a biorational reduced such a risk, as this cost-effectively reduced ESFB and controlled aphids and jassids.

\subsection{Economic viability of the tested IPM}

The highest marketable yield was, in both years, obtained when pheromone trapping was accompanied by 4 times trap-based spraying of a biorational insecticide (Table 1). This yield was 12-14 $\mathrm{t} \mathrm{ha}^{-1}$ higher than farmers' conventional practice or the no treatment control, which were not significantly different. Pheromone trapping alone yielded 8-9 tha ${ }^{-1}$ more than farmers' practice. Yields from pheromone trapping alone or combined with conventional insecticide spraying were comparable. The difference between the net value of the harvest with improved management and that with farmers' practice demonstrates an obvious advantage of IPM over farmers' current practice (Table 1). Across the 2 years, it appeared that, by practicing improved management, farmers could earn $€ 1300$ $1800 \mathrm{ha}^{-1}$ more in years when eggplant prices were normal, but still $€ 900-1200 \mathrm{ha}^{-1}$ more in years with low prices, compared with their current practice (Table 1). If farmers installed only pheromone traps they could, depending on eggplant prices, earn $€ 1390$ to $€ 980$ ha $^{-1}$ more than their current practice, at roughly $45 \%$ of the cost of their conventional practice. In year 1, combining conventional insecticides with pheromone trapping reduced income. Therefore, because of proposals from the involved farmers, this practice was not repeated in year 2 . However, farmers might earn a further additional net $€ 392 \mathrm{ha}^{-1}$ in years with normal prices and $€ 176 \mathrm{ha}^{-1}$ in years with low prices if they combined biorational insecticide spraying with pheromone trapping (Table 1) compared with only installing pheromone traps, but at substantial extra costs. Interestingly, farmers could gain $€ 420 \mathrm{ha}^{-1}$ by taking no insect protection actions compared with their current practices, simply because costs would be reduced. The costs of farmers' practice over doing nothing were $€ 485 \mathrm{ha}^{-1}$, pheromone trapping costs $€ 200 \mathrm{ha}^{-1}$ less than farmers' practice, costs of combining pheromone trapping, and trap-based limited spraying of biorational insecticide were comparable with farmers' practice; however, the aforesaid improved practices led 
to $€ 1300-1800 \mathrm{ha}^{-1}$ more income. The investment in pheromone trapping of $€ 280 \mathrm{ha}^{-1}$ provided a net extra income of between $€ 530$ and $€ 970$ ha $^{-1}$ compared with the untreated control, depending on the eggplant price. For farmers, who currently invest $€ 485 \mathrm{ha}^{-1}$ on insecticides at no profit, this investment should be feasible. This provides evidence that farmers' practice is not based on an assessment of costs and benefits.

Besides insect pests, a major production challenge in the area is bacterial wilt, observed to lead to between 20 and $70 \%$ plant loss (Nahar et al. 2019). On average, the experimental fields suffered $27-29 \%$ plant loss to bacterial wilt. There is a risk of investment in ESFB IPM being lost due to plant loss through bacterial wilt, a point raised by farmers when negotiating the present study; they stated "what if we do not have plants, where will we implement IPM for ESFB?" (Table 2). Indeed, farmers are not interested in a single-problem-oriented IPM when one problem constrains another economically (Horne et al. 2008; Parsa et al. 2014). We therefore used a simple model to assess breakeven points of different IPM options and found that pheromone trapping provided a positive income at plant loss to bacterial wilt of up to $59-62$ or $73-75 \%$ in years with low or normal eggplant prices, respectively, well above the breakeven points of 27-38 to 52-60\% for farmers' practice (Table 1). Therefore, the risk of a negative income is much lower when pheromone traps are used either alone or combined with biorational insecticides than with current farmers' practice.

\subsection{Practical applicability of the tested IPM}

From the beginning to the end of the study, during negotiations, monthly discussions, and joint field observations, we recorded farmers' reactions to, and observations on, different aspects of the studied IPM options. Only the most telling quotes are presented here (Table 2). We identified four major bottlenecks in the tested IPM options: (i) farmers' knowledge on ESFB biology is partial at best, as they could not relate caterpillars and adult moths; (ii) traps and lures are not yet available at village level; (iii) farmers are not in favor of labor-adding practices and thus rejected sanitation; and (iv) farmers questioned the efficacy of IPM if traps are not installed in a network of farmers' fields as in the present study, but installed in individual fields.

During initial discussions, farmers indicated that they were familiar with pheromone trapping because previously there had been a farmers' field school training in the village. However, when asked what would be caught in traps, they answered keera (caterpillar). Soon after the first trap catches, farmers wondered why "strange flies" were caught instead of the caterpillars damaging their crops. When asked about the fate of caterpillars, they answered "caterpillar rots inside fruit". Apparently, farmers had difficulty understanding the ESFB lifecycle. Therefore, farmers' knowledge could be a fundamental constraint to IPM implementation (Litsinger et al. 2009). Correct farmers' knowledge on insect biology and ecology is an important component to make strategic

Table 2 Summary of selected statements made by farmers during the study and the context in which these were made

\begin{tabular}{|c|c|}
\hline Statement & Context \\
\hline $\begin{array}{l}\text { "Whenever we see infested shoots or fruits, we remove them. We are } \\
\text { practicing this from our fathers' time. We cannot do it weekly or } \\
\text { regularly as structured practice, we do not have time for that." }\end{array}$ & $\begin{array}{l}\text { During a negotiation meeting where we decided which improved practices } \\
\text { would be tested in the field, it was suggested that farmers remove infested } \\
\text { shoots and fruits as a practice. Most of the farmers immediately rejected } \\
\text { the proposal. Two farmers did it once, and after that they reported it was } \\
\text { too time consuming and laborious. Therefore, they decided not to } \\
\text { practice it anymore. }\end{array}$ \\
\hline $\begin{array}{l}\text { "What is inside the shoots and fruits is not in the traps. Traps catch flies } \\
\text { only. Flies are not problem to us." }\end{array}$ & $\begin{array}{l}\text { When pheromone trapping was proposed to farmers, most of them said that } \\
\text { they knew about traps but that they catch morphs other than caterpillars. } \\
\text { Farmers were confused by trap catches (whether it was some kind of fly } \\
\text { or ESFB adults as described by the researcher) until the infestation } \\
\text { became stabilized. One farmer attempted to remove traps at the beginning } \\
\text { of the field study. }\end{array}$ \\
\hline "Keera (caterpillar) rots inside fruits." & $\begin{array}{l}\text { When farmers were asked about the caterpillars' lifecycle, they could not } \\
\text { answer how caterpillars are born and how they develop. }\end{array}$ \\
\hline $\begin{array}{l}\text { "We cannot kill them even if we spray regularly. How could you tell us not } \\
\text { to spray?" }\end{array}$ & This was a response when only pheromone trapping was proposed. \\
\hline "If we do not have plants, where will we apply ESFB IPM?" & $\begin{array}{l}\text { Every year, farmers' fields suffer from bacterial wilt. Farmers indicated that } \\
\text { just working on an ESFB IPM was not that relevant to them. }\end{array}$ \\
\hline $\begin{array}{l}\text { "I think I will attract more insects if I am the only person in the landscape } \\
\text { with traps." "I think that the trap will attract more insects if I am alone." }\end{array}$ & $\begin{array}{l}\text { Farmers expressed their worry about using traps at individual level. They } \\
\text { think that they will have more insects in their fields if they are the only } \\
\text { one using traps. }\end{array}$ \\
\hline
\end{tabular}


IPM successful. Without it, farmers will expect little benefit from these traps. Successful adoption requires knowledge on how to correctly implement the practice and what to expect from it, not just on the practice itself. However, even if that knowledge is improved now, the availability of IPM materials such as traps, pheromone lures, and biorational insecticides is limited in the study area, whereas farmers can buy broad spectrum insecticides on their doorstep. If these inputs are not made more readily available to farmers, the continued practice of improved IPM is likely to be negligible. During negotiations about improved management, the proposed removal of infested shoots and fruits as previously recommended by Alam et al. (2006) was immediately rejected. Indeed, IPM requiring more labor is unlikely to succeed (Beckmann and Wesseler 2003). Our results can be aligned with the findings of Peshin (2013), who reported that cotton IPM farmers in India strongly adopted timely sowing as it is simple, requiring no extra labor; on the other hand, monitoring insects for economic threshold level was poorly adopted because it required skill and labor. Therefore, if we want farmers to implement IPM, we need to think rationally about farmers' how-to-do knowledge, skills, labor, and availability of IPM materials.

In the present study, fields of participating farmers made a network of nearby traps because of the extent of the study. In other words, this study shows that, as a trapping network, pheromone traps reduced shoot and fruit infestation and increased yield. We have not yet answered the question of whether trapping also works when a small landholder installs it in an individual field. This was also the concern of farmers who stated: "I think that the trap will attract more insects if I am alone" (Table 2).

\section{Conclusion}

The present study tested an array of options with farmers. From a technical perspective, pheromone trapping alone or in combination with limited biorational spraying can improve marketable yields and farmers' income at comparable input costs in terms of cash and labor. Therefore, farmers can either choose only pheromone trapping or add biorational spraying to trapping. We recommended and supervised firstly single trap monitoring on a few plots, followed by the installation of traps for mass trapping after the first moths were trapped 25-30 DAT. Although we did not research the extent to which infestation would be reduced if traps were installed at flowering or fruiting stage, data on population dynamics (Fig. 2e, f) support the decision to avoid risks of substantial damage by waiting for longer than the first observations of moths in traps.
Use of only pheromone trapping and refraining from insecticide use would be challenging for farmers currently used to calendar-based spraying (Morse 2009). Therefore, a combination of trapping with limited biorational spraying as a fallback option could increase the chance of adoption. This would also provide control if sucking insect populations got out of hand and thereby alleviate the risk of failure to introduce the new regime. However, in this study, the timing of biorational spraying was guided by the researcher. Only with more training may farmers independently be able to decide when to spray based on trap-catch monitoring. Alternatively, farmers could be instructed to spray biorationals at roughly 30 35-day intervals from the moment of first moth appearance to target eggs and 1st instar caterpillars. In addition, a critical level of 4 moths per trap per week could be introduced as the level above which spraying may be useful.

Although farmers stated that managing traps was not more difficult and time consuming than conventional spraying, from a practical implementation perspective, given farmers' contexts, two major constraints were observed: (i) farmers' ability to comprehend the moth's lifecycle and the trapping mechanism and (ii) unavailability of pheromone lures, traps, and biorationals at village level. Without at least addressing these constraints, IPM implementation will not succeed.

To the best of our knowledge, this is the first study to disentangle the technical efficacy and the economic viability of pheromone-trap-based IPM from its practical applicability for the targeted smallholder vegetable growers. It allowed us not only to identify best options for and with farmers, but also to assess the underlying complexity of making IPM work for smallholder eggplant growers. This study was conducted in Bangladesh, but the findings on practical constraints are most likely valid across South and South-East Asia where the same pest is a major problem and smallholders' knowledge levels and farming conditions are comparable. This provides a novel insight for IPM researchers on the underlying complexity of IPM and the research approach that could help in designing workable approaches with farmers.

From the observations and discussions in the field, we propose to study further: (i) whether results would be different when traps are not installed as a network as tested in the present study and consequently what density of trapping is needed to manage ESFB and whether this requires community-level organization; (ii) whether the involved farmers retain or abandon the tested IPM and also whether it spreads among other farmers in the same village; and (iii) whether participant farmers' knowledge on ESFB biology and pheromone trapping improves. 
Acknowledgments We acknowledge Pirijpur farmers for participating in the study and allocating land to tests, the farmer trainers for assistance in the study, the villagers for their cooperation, and IPM laboratory of the Department of Entomology (BAU) for identifying natural enemies. We also acknowledge Bob Douma, Assistant Professor at WUR, for his support in the statistical analysis and Catherine O'Dea Hughes for language editing.

Authors' contributions Conceptualization, N.N., M.M.U., P.d.J., P.C.S., and T.J.S.; methodology, N.N. and T.J.S.; data collection, N.N.; statistical analyses, N.N. and T.J.S.; writing original draft, N.N., M.M.U., P.d.J., P.C.S., and T.J.S.; writing review and editing, N.N., T.J.S., and P.C.S.; funding acquisition, T.J.S.; supervision, T.J.S., P.C.S., P.d.J., and M.M.U.

Funding information This project was funded by NUFFIC (The Dutch Organization for Internationalization in Education), The Netherlands, under its NICHE program (grant number NUFFIC-NICHE-BGD-156), a collaboration between Wageningen University and Research (WUR) and Bangladesh Agricultural University (BAU).

\section{Compliance with ethical standards}

Conflict of interest The authors declare that they have no conflicts of interest.

Open Access This article is licensed under a Creative Commons Attribution 4.0 International License, which permits use, sharing, adaptation, distribution and reproduction in any medium or format, as long as you give appropriate credit to the original author(s) and the source, provide a link to the Creative Commons licence, and indicate if changes were made. The images or other third party material in this article are included in the article's Creative Commons licence, unless indicated otherwise in a credit line to the material. If material is not included in the article's Creative Commons licence and your intended use is not permitted by statutory regulation or exceeds the permitted use, you will need to obtain permission directly from the copyright holder. To view a copy of this licence, visit http://creativecommons.org/licenses/by/4.0/.

\section{References}

Alam SN, Hossain MI, Rouf FMA, Jhala RC, Patel MG, Rath LK, Sengupta A, Baral K, Shylesha AN, Satpathy S, Shivalingaswamy TM, Cork A, Talekar NS (2006) Implementation and promotion of an IPM strategy for control of eggplant fruit and shoot borer in South Asia. Technical bulletin no. 36. AVRDC publication number 06672. AVRDC - the world vegetable center, Shanhua, Taiwan

Beckmann V, Wesseler J (2003) How labour organization may affect technology adoption: an analytical framework analyzing the case of integrated pest management. Environ Dev Econ 8:437-450. https://doi.org/10.1017/s1355770x0300238

Biondi A, Mommaerts V, Smagghe G, Vinuela E, Zappala L, Desneux N (2012) The non-target impact of spinosyns on beneficial arthropods. Pest Manag Sci 68:1523-1536. https://doi.org/10.1002/ps.3396

Bret BL, Larson LL, Schoonover JR, Sparks TC, Thompson GD (1997) Biological properties of Spinosad. Down Earth 52:6-13

Chowdhury MA, Fakhruddin AN, Islam MN, Moniruzzaman M, Gan SH, Alam MK (2013) Detection of the residues of nineteen pesticides in fresh vegetable samples using gas chromatography-mass spectrometry. Food Control 34:457-465. https://doi.org/10.1016/j. foodcont.2013.05.006
Cork A, Alam SN, Das A, Das CS, Ghosh GC, Farman DI, Hall DR, Maslen NR, Vedham K, Phythian SJ, Rouf FM (2001) Female sex pheromone of brinjal fruit and shoot borer, Leucinodes orbonalis blend optimization. J Chem Ecol 27(9):1867-1877

Cruz I, Figueiredo MD, Silva RB, Silva IF, Paula CD, Foster JE (2012) Using sex pheromone traps in the decision-making process for pesticide application against fall armyworm (Spodoptera frugiperda [Smith] [Lepidoptera: Noctuidae]) larvae in maize. Int J Pest Manag 58:83-90. https://doi.org/10.1080/09670874.2012.655702

El-Sayed AM, Suckling DM, Wearing CH, Byers JA (2006) Potential of mass trapping for long-term pest management and eradication of invasive species. J Econ Entomol 99:1550-1564. https://doi.org/ 10.1093/jee/99.5.1550

Galvan TL, Koch RL, Hutchinson WD (2005) Toxicity of commonly used insecticides in sweet corn and soybean to multicolored Asian lady beetle (Coleoptera: Coccinellidae). J Econ Entomol 98(3):780 789

Hanur VS, Boopal K, Arya VV, Srividya KN, Saraswathi MS (2014) Why is management of brinjal shoot and fruit borer, Leucinodes orbonalis Guenee, difficult? An examination into the pest's unique feeding behavioral biology. J Entomol Zool Stud 2(6):257-260

Hill MP, Macfadyen S, Nash MA (2017) Broad spectrum pesticide application alters natural enemy communities and may facilitate secondary pest outbreaks. PeerJ 5:4179. https://doi.org/10.7717/peerj. 4179

Horne PA, Page J, Nicholson C (2008) When will integrated pest management strategies be adopted? Example of the development and implementation of integrated pest management strategies in cropping systems in Victoria. Aust J Exp Agric 48:1601-1607. https://doi.org/10.1071/ea08072

Kalawate A, Dethe MD (2012) Bioefficacy study of biorational insecticide on brinjal. J Biopestic 5(1):75-80

Litsinger JA, Libetario EM, Canapi BL (2009) Eliciting farmer knowledge, attitudes, and practices in the development of integrated pest management programs for rice in Asia. In: Peshin R, Dhawan AK (eds) Integrated pest management: dissemination and impact. Springer, Dordrecht, pp 119-273. https://doi.org/10.1007/978-14020-8990-9_5

Liu Y, Li X, Zhou C, Liu F, Mu W (2016) Toxicity of nine insecticides on four natural enemies of Spodoptera exigua. Sci Rep 6:39060. https:// doi.org/10.1038/srep39060

Miah SJ, Hoque A, Paul A, Rahman A (2014) Unsafe use of pesticide and its impact on health of farmers: a case study in Burichong Upazila, Bangladesh. J Environ Sci Toxicol Food Technol 8:57-67. https:// doi.org/10.9790/2402-08155767

Mohiuddin M, Hossain MM, Rahman AK, Palash MS (2009) Socioeconomic study of insecticide use on vegetable cultivation at farm level in Chittagong region. J Bangl Agric Univ 7:343-350. https:// doi.org/10.3329/jbau.v7i2.4745

Morse S (2009) Chapter 36 - IPM: ideals and realities in developing countries. In: Radcliffe EB, Hutchison WD, Cancelado RE (eds) Integrated pest management: concepts, tactics, strategies and case studies. Cambridge University Press, pp 458-470. https://doi.org/ 10.1017/cbo9780511626463.037

Morse S, Buhler W (1997) IPM in developing countries: the danger of an ideal. Integr Pest Manag Rev 2:175-185

Nahar N, Islam MR, Uddin MM, de Jong P, Struik PC, Stomph TJ (2019) Disease management in eggplant (Solanum melongena L.) nurseries also reduces wilt and fruit rot in subsequent plantings: a participatory testing in Bangladesh. Crop Prot 120:113-124. https://doi.org/10. 1016/j.cropro.2019.02.018

Parsa S, Morse S, Bonifacio A, Chancellor TC, Condori B, Crespo-Pérez V, Hobbs SL, Kroschel J, Ba MN, Rebaudo F, Sherwood SG (2014) Obstacles to integrated pest management adoption in developing countries. Proc Natl Acad Sci U S A 111:3889-3894. https://doi. org/10.1073/pnas.1312693111 
Peshin R (2013) Farmers' adoptability of integrated pest management of cotton revealed by a new methodology. Agron Sustain Dev 33:563572. https://doi.org/10.1007/s13593-012-0127-4

Pimentel D (1995) Amounts of pesticides reaching target pests: environmental impacts and ethics. J Agric Environ Ethics 8:17-29. https:// doi.org/10.1007/bf02286399

Rahman MM, Rahman MM (2009) Study on the development of resistance in brinjal shoot and fruit borer against different insecticides. World J Zool 4(2):137-143

Rosell G, Quero C, Coll J, Guerrero A (2008) Biorational insecticides in pest management. J Pestic Sci 33(2):103-121

Ruberson J, Nemoto H, Hirose Y (1998) Chapter 11: pesticides and conservation of natural enemies in pest management. In: Barbosa P (ed) Conservation biological control. Academic Press, pp 207 220. https://doi.org/10.1016/b978-012078147-8/50057-8

Sarfraz M, Dosdall LM, Keddie BA (2005) Spinosad: a promising tool for integrated pest management. Outlooks Pest Manag 16:78-84. https://doi.org/10.1564/16apl09

Scholz BC, Zalucki MP (2000) The effects of two new insecticides on the survival of adult Trichogramma pretiosum Riley in sweet corn. In: Austin AD, Dowton M (eds) Hymenoptera: evolution, biodiversity and biological control. CSIRO Publishing, Canberra, pp 381-387

Srinivasan R (2008) Integrated pest management for eggplant fruit and shoot borer (Leucinodes orbonalis) in south and Southeast Asia: past, present and future. J Biopestic 1(2):105-112
Van Leeuwen T, Dermauw W, Van De Veire M, Tirry L (2005) Systemic use of spinosad to control the two-spotted spider mite (Acari: Tetranychidae) on tomatoes grown in rockwool. Exp Appl Acarol 37:93-105. https://doi.org/10.1007/s10493-005-0139-8

Weintraub PG, Mujica N (2006) Note: systemic effects of Spinosad insecticide on Liriomyza huidobrensis larvae. Phytoparasitica 34:2124. https://doi.org/10.1007/bf02981335

Williams T, Valle J, Viñuela E (2003) Is the naturally derived insecticide Spinosad® compatible with insect natural enemies? Biocontrol Sci Tech 13(5):459-475. https://doi.org/10.1080/ 0958315031000140956

Witzgall P, Kirsch P, Cork A (2010) Sex pheromones and their impact on pest management. J Chem Ecol 36:80-100. https://doi.org/10.1007/ s10886-009-9737-y

Wyckhuys KA, Heong KL, Sanchez-Bayo F, Bianchi FJ, Lundgren JG, Bentley JW (2019) Ecological illiteracy can deepen farmers' pesticide dependency. Environ Res Lett 14:093004. https://doi.org/10. 7287/peerj.preprints. 27579

Zhu P, Kong F, Yu S, Yu Y, Jin S, Hu X, Xu J (1987) Identification of the sex pheromone of eggplant borer Leucinodes orbonalis Guenee (Lepidoptera: Pyralidae). Z Naturforsch 42:1347-1348. https://doi. org/10.1515/znc-1987-11-1235

Publisher's note Springer Nature remains neutral with regard to jurisdictional claims in published maps and institutional affiliations. 